\title{
Detection of Four New Tomato Viruses in Serbia Using Post Hoc High-Throughput Sequencing Analysis of Samples From a Large-Scale Field Survey
}

\author{
Ana Vučurović, ${ }^{1,2, \dagger}$ Denis Kutnjak, ${ }^{1}$ Nataša Mehle, ${ }^{1}$ Ivana Stanković, ${ }^{2}$ Anja Pecman, ${ }^{1}$ Aleksandra Bulajić, ${ }^{2}$ Branka Krstić, ${ }^{2}$ and \\ Maja Ravnikar ${ }^{1,3}$ \\ ${ }^{1}$ Department of Biotechnology and Systems Biology, National Institute of Biology, 1000 Ljubljana, Slovenia \\ ${ }^{2}$ Institute of Phytomedicine, Department of Phytopathology, University of Belgrade-Faculty of Agriculture, 11080 Belgrade, Serbia \\ ${ }^{3}$ University of Nova Gorica, 5000 Nova Gorica, Slovenia
}

\begin{abstract}
Tomato production worldwide is affected by numerous plant virus species. The early and accurate detection of viruses is a critical step for disease control. However, the simultaneous detection of the most known tomato viruses can be difficult because of the high number and diversity of tomato-infecting viruses. Here, we have identified four new viruses in Serbia by applying target-independent small RNA high-throughput sequencing (HTS). HTS was applied on pools of samples and separate samples, in total comprising 30 tomato samples that exhibited (severe) virus-like symptoms and were collected in Serbia during three annual surveys (2011 to 2013). These samples had previously tested negative for the presence of 16 tomato viruses

tomato. The tomato torrado virus was detected at one locality with devastating yield losses. The southern tomato virus was detected at two localities, and the spinach latent virus was detected at one locality. In addition, we detected the presence of one already-known virus in Serbia, the tomato spotted wilt orthotospovirus. All the HTS results were subsequently confirmed by targeted detection methods. In this study, the successful application of post hoc HTS testing of a limited number of pooled samples resulted in the discovery of new viruses. Thus, our results encourage the use of HTS in research and diagnostic laboratories, including laboratories that have limited resources to resolve disease etiology.
\end{abstract} using targeted detection methods. Three divergent complete genome sequences of Physostegia chlorotic mottled virus were obtained from different localities, indicating for the first time that this virus is widespread in Serbia and might represent an emergent viral pathogen of
Keywords: detection, high-throughput sequencing, identification, small RNAs, tomato, viruses
The tomato is the third most important vegetable in Serbia and is cultivated on approximately 10,000 ha with yields of $15.9 \mathrm{t} / \mathrm{ha}$ (FAO 2016). The Serbian tomato market was worth approximately 24 million euros in 2018 (PKS 2019). Viral diseases are the major factor limiting tomato production worldwide, causing severe economic losses of millions of dollars (Hansen and Lapidot 2012). Because of the high diversity of viruses that infect tomato, their ever-increasing number $(\mathrm{Xu}$ et al. 2017), coinfection with multiple viruses, and the similarity between virus disease symptoms and physiological or nutritional disorders, a timely and accurate identification of the causal agents using generic detection methods is necessary (Hanssen et al. 2010; Lievens and Thomma 2005; Moyer et al. 1999; Wickes and Wiederhold 2018; Xu et al. 2017). The importance of viruses in tomato production has triggered comprehensive surveys in almost all tomato-growing localities in the world with the aim to determine the most prevalent and harmful virus species.

${ }^{\dagger}$ Corresponding author: A. Vučurović; ana.vucurovic@ nib.si

Funding: This research was supported by European Cooperation in Science and Technology (COST Action FA1407); Slovenian Research Agency Program grant P4-0165; ArimNet Emaramb grant GA_618127; Ministry of Education, Science, and Technological Development, Republic of Serbia grant 451-03-9/2021-14/200116; and Serbian-Slovenian bilateral project "Application of Next Generation Sequencing in Detection of Tomato Viruses in Serbia and Slovenia" project no. 004.

*The $\boldsymbol{e}$-Xtra logo stands for "electronic extra" and indicates there are supplementary materials published online.

The author(s) declare no conflict of interest.

Accepted for publication 22 March 2021.

Copyright ( 2021 The Author(s). This is an open access article distributed under the CC BY-NC-ND 4.0 International license.
A previous study on tomato viruses in Serbia indicated the presence of 10 viruses (Mijatović et al. 2000). However, a comprehensive study on tomato viruses in Serbia showed a significant shift in population diversity, revealing the presence of only six viruses: cucumber mosaic virus (CMV), potato virus Y (PVY), tomato spotted wilt orthotospovirus (TSWV), alfalfa mosaic virus (AMV), tomato mosaic virus (ToMV), and tobacco mosaic virus (TMV); the importance of CMV and PVY in both single and double infections was highlighted (Nikolić et al. 2018). In 2019, a new virus infecting tomato, tomato infectious chlorosis virus (TICV), was reported in Serbia (Vučurović et al. 2019). In the surveys (Nikolić et al. 2018; Nikolić 2018) conducted from 2011 to 2015 in Serbia, $26.4 \%$ of the samples that exhibited virus-like symptoms were negative for the presence of 16 viruses. In these studies, standard targeted virological techniques, i.e., double-antibody sandwich enzyme-linked immunosorbent assay (DAS-ELISA) or reverse transcription-polymerase chain reaction (RT-PCR), were used.

However, the aforementioned methods have significant limitations in regard to their multiplexing levels, as they require specific tests for one or more targets, which is not feasible in the case of tomatoes with $>130$ known viruses (Hanssen et al. 2010). Advances in the field of sequencing technology have made high-throughput sequencing (HTS) affordable to a broader user base. HTS has revolutionized virology, providing a valuable generic tool for virus detection, discovery, or diversity studies in, e.g., grapevine and tomatoes (Coetzee et al. 2010; Ho and Tzanetakis 2014; Visser et al. 2016; Villamor et al. 2019; Wang et al. 2013; Xu et al. 2017; Zhao et al. 2013), potentially enabling the simultaneous detection of numerous viruses. Methods based on HTS were first used for plant virus detection in 2009 (Adams et al. 2009; Al Rwahnih et al. 2009; Kreuze et al. 2009), and these methods have been progressively reaching the diagnostic field ever since (Massart et al. 2014), being widely employed for the detection of plant viruses (Ho and Tzanetakis 2014; Hily et al. 2018; Kutnjak et al. 2014; Massart et al. 2014; Pecman et al. 2017, 2018; Zheng et al. 2017). One of the HTS approaches that is frequently used for plant virus detection is the sequencing of small (s)RNAs (Kreuze et al. 2009), which enables the detection of RNA viruses, DNA viruses, and viroids (Itaya et al. 2001; Pecman et al. 2017). 
Here, we used target-independent sRNA HTS to supplement traditional virus surveys. We explored the yet-unknown part of the tomato virome in a selected set of the above-mentioned collected symptomatic samples, which tested negative for the presence of 16 viruses using targeted detection methods (Nikolić 2018; Nikolić et al. 2018). We aimed to detect new or unexpected viruses in tomatoes in Serbia and to resolve some of the unknown etiologies of tomato diseases in the country.

\section{Materials and Methods}

Sample selection. The samples used in this study originate from a five-year survey (2011 to 2015) conducted at 136 localities in 22 districts of Serbia (Nikolić 2018; Nikolić et al. 2018). For this study, we selected 30 out of 920 samples tested negative for the 16 viruses in the previous studies (Nikolić 2018; Nikolić et al. 2018; Supplementary Table S1) collected from 11 localities between 2011 and 2013 (Table 1, Supplementary Fig. S1). The tomato samples selected for this study exhibited symptoms resembling those caused by viruses, including leaf mosaic, chlorosis, deformations, blistering, and edge necrosis, and/or fruit mosaic, marbling, deformations, and necrotic line patterns (Fig. 1). Sample selection was performed by taking into account all the results obtained by targeted methods in Nikolić (2018) and Nikolić et al. (2018) and photo documentation of symptoms for each particular sample, excluding the samples in which symptoms could be attributed to nutritional disorders, other pathogens, and influence of the environmental conditions.

Small RNA extraction, pooling, and Illumina sequencing. Total RNA was extracted from $100 \mu \mathrm{g}$ of freeze-dried leaf material from each of the 30 individual samples using TRIzol reagent (Life Technologies, Invitrogen, Carlsbad, CA) following the manufacturer's instructions. A NanoDrop spectrophotometer (ND-1000, NanoDrop Technology, Wilmington, DE) was used to determine the quality of extraction and total RNA concentration.

The samples were then pooled according to locality, year of collection, and symptoms for two localities (Togočevce and Počekovina) (Table 1). Six samples were sequenced individually, while 24 were pooled into five groups and subjected to sRNA HTS (Table 1). The RNA pools were prepared by mixing equal amounts of RNAs originating from different samples to ensure a uniform concentration of each sample in the pool. Total RNAs were sent to SeqMatic LLC (Fremont, CA) for library preparation and sequencing, and sRNA libraries (11 in total) were constructed (TailorMix miRNA Sample Preparation Kit V2, SeqMatic LLC) and multiplexed in one lane of Illumina HiSeq 2500 (Illumina) in $1 \times 50 \mathrm{bp}$ mode.

HTS data processing and detection of viral reads. Raw sequencing reads were imported to CLC Genomic Workbench version 11.0 (CLC Bio, Qiagen, Aarhus, Denmark). Sequencing adapters were trimmed from the reads, and quality control of the reads was performed; the number and average length of the sequencing reads for

Table 1. Tomato samples/pools from Serbia

\begin{tabular}{|c|c|c|c|c|c|c|c|c|}
\hline \multirow[b]{2}{*}{$\begin{array}{l}\text { Sample } \\
\text { designation }\end{array}$} & \multirow[b]{2}{*}{$\begin{array}{l}\text { Sequenced } \\
\text { pool }\end{array}$} & \multirow[b]{2}{*}{ Symptoms } & \multirow[b]{2}{*}{$\begin{array}{l}\text { Locality/type } \\
\text { of production }\end{array}$} & \multirow[b]{2}{*}{$\begin{array}{l}\text { Result by } \\
\text { HTS }\end{array}$} & \multicolumn{4}{|c|}{ Confirmation } \\
\hline & & & & & ELISA & RT-PCR & $\begin{array}{l}\text { RT-qPCR } \\
\text { (Cq value) }\end{array}$ & Sanger \\
\hline $236-11$ & p_1 & Leaf crinkling and deformations & Počekovina 1/ & - & $\rho^{\mathrm{a}}$ & I & l & / \\
\hline $240-11$ & & & Greenhouse & & / & l & l & / \\
\hline 243-11 & & & & & / & / & / & / \\
\hline $215-12$ & $\mathrm{NA}^{\mathrm{b}}$ & Leaf crinkling and deformations & $\begin{array}{l}\text { Mačkovac/ } \\
\text { Greenhouse }\end{array}$ & - & / & / & l & / \\
\hline $232-11$ & p_3 & Leaf crinkling and mosaic & Počekovina 2/ & $\mathrm{STV}^{\mathrm{c}}$ & / & + & l & / \\
\hline $239-11$ & & & Greenhouse & & / & - & I & / \\
\hline $9-12$ & p_4 & Leaf mottling & $\begin{array}{l}\text { Debrc/ } \\
\text { Greenhouse }\end{array}$ & ToTV & l & + & $+(36.0)$ & l \\
\hline $10-12$ & & Whitish mottling & & & l & + & $+(33.0)$ & / \\
\hline $11-12$ & & Leaf crinkling and deformations & & & / & + & $+(34.1)$ & / \\
\hline $12-12$ & & $\begin{array}{l}\text { Leaf crinkling, deformations, } \\
\text { and mosaic }\end{array}$ & & & / & + & $+(23.0)$ & + \\
\hline $13-12$ & & Deformations and necrosis & & & / & + & $+(20.3)$ & / \\
\hline $14-12$ & & Deep lobes & & & / & + & $+(33.4)$ & / \\
\hline $15-12$ & & Yellow mosaic & & & / & + & $+(22.3)$ & + \\
\hline $16-12$ & & Shoestring & & & / & + & $+(34.3)$ & / \\
\hline $18-12$ & & Bronzing & & & / & + & $+(21.0)$ & / \\
\hline $19-12$ & & Yellow mosaic & & & / & + & $+(27.4)$ & / \\
\hline $20-12$ & & Deformations and necrosis & & & l & + & $+(32.4)$ & / \\
\hline $210-12$ & p_5 & Stunting & Varvarin/ & - & / & l & I & / \\
\hline $212-12$ & & & Open field & & & & & \\
\hline $328-12$ & NA & Stunting & $\begin{array}{l}\text { Togočevce 1/ } \\
\text { Greenhouse }\end{array}$ & - & / & / & l & / \\
\hline $232-12$ & NA & $\begin{array}{l}\text { Leaf mottling, fruit mottling, } \\
\text { and uneven ripening }\end{array}$ & $\begin{array}{l}\text { Medveda/ } \\
\text { Greenhouse }\end{array}$ & PhCMoV & EMDV - & + & l & + \\
\hline $238-12$ & NA & $\begin{array}{l}\text { Leaf mottling, fruit mottling, } \\
\text { and uneven ripening }\end{array}$ & $\begin{array}{l}\text { Počekovina 3/ } \\
\text { Greenhouse }\end{array}$ & PhCMoV & EMDV - & + & l & + \\
\hline $226-13$ & p_9 & $\begin{array}{l}\text { Leaf mottling and deformations } \\
\text { and ring necrosis on fruits }\end{array}$ & $\begin{array}{l}\text { Kupusina/ } \\
\text { Greenhouse }\end{array}$ & $\begin{array}{l}\text { TSWV, } \\
\text { SpLV }\end{array}$ & l & $\mathrm{SpLV}-$ & $\begin{array}{c}\text { TSWV - } \\
(\text { neg/neg/34.9 })\end{array}$ & / \\
\hline $227-13$ & & & & & l & SpLV - & TSWV + (31.6) & / \\
\hline $228-13$ & & & & & / & SpLV - & TSWV + (30.8) & / \\
\hline $229-13$ & & & & & / & SpLV - & TSWV + (32.1) & / \\
\hline $230-13$ & & & & & / & $\mathrm{SpLV}+$ & TSWV + (22.7) & / \\
\hline $232-13$ & & & & & l & SpLV - & TSWV + (32.3) & / \\
\hline $200-13$ & NA & Prominent crinkling & $\begin{array}{l}\text { Donji Tavankut/ } \\
\text { Open field }\end{array}$ & - & l & I & 1 & / \\
\hline $323-12$ & NA & Fruit mottling & $\begin{array}{l}\text { Togočevce 2/ } \\
\text { Greenhouse }\end{array}$ & $\begin{array}{c}\text { PhCMoV, } \\
\text { STV }\end{array}$ & EMDV - & $\begin{array}{l}\mathrm{PhCMoV}+ \\
\text { STV + }\end{array}$ & l & + \\
\hline
\end{tabular}


every sample sequenced are provided in Supplementary Table S2. We used a workflow for the detection of plant viruses to further analyze sRNA sequencing reads (the parameters used in the analyses are provided in Supplementary Tables S3 to S5), as described by Pecman et al. (2017). Additionally, we compared all the de novo assembled contigs produced by the pipeline to all sequences deposited in the National Center for Biotechnology Information (NCBI) GenBank using BLASTn against the nt database (February 2017) and BLASTx against the $\mathrm{nr}$ database (February 2017). To obtain potentially improved assemblies of viral genomes, we also ran de novo assembly for all the samples using SPAdes version 3.6.1 (Bankevich et al. 2012) and the input file of the single-read library and set the k-mer lengths to $15,17,19$, and 21, with the option -careful.

The construction of viral consensus genome sequences. To confirm the presence of each virus detected by the used pipeline, we performed mapping of the reads to the complete viral genome sequences of the most similar viral isolates from the NCBI GenBank database. We then visually inspected the individual mappings. Validation of each corrected consensus genome was performed by mapping all de novo generated contigs obtained by CLC Genomics Workbench and SPAdes to the corresponding corrected consensus genome sequences. Visual inspection of the mapping results was performed to detect possible differences between the de novo contigs and the corrected consensus genome sequence. Discerned conflicts were investigated by inspecting the mapping of the reads obtained by sequencing.

Confirmation of the HTS results. The detection of viruses by HTS was confirmed using DAS-ELISA, RT-PCR, and/or reverse transcription quantitative real-time PCR (RT-qPCR).

For RT-PCR and RT-qPCR, the same total RNA extracts were used as for HTS. RT-PCR was performed using primers designed in this study for Physostegia chlorotic mottle virus (PhCMoV) (amplifying a 905-nucleotide [nt] long fragment of the $5^{\prime}$ end of the L geneRNA-directed RNA polymerase - and $3^{\prime}$ end of the $5^{\prime}$ trailer) or previously developed primers for tomato torrado virus (ToTV), southern tomato virus (STV), and spinach latent virus (SpLV) (Supplementary Table S6).

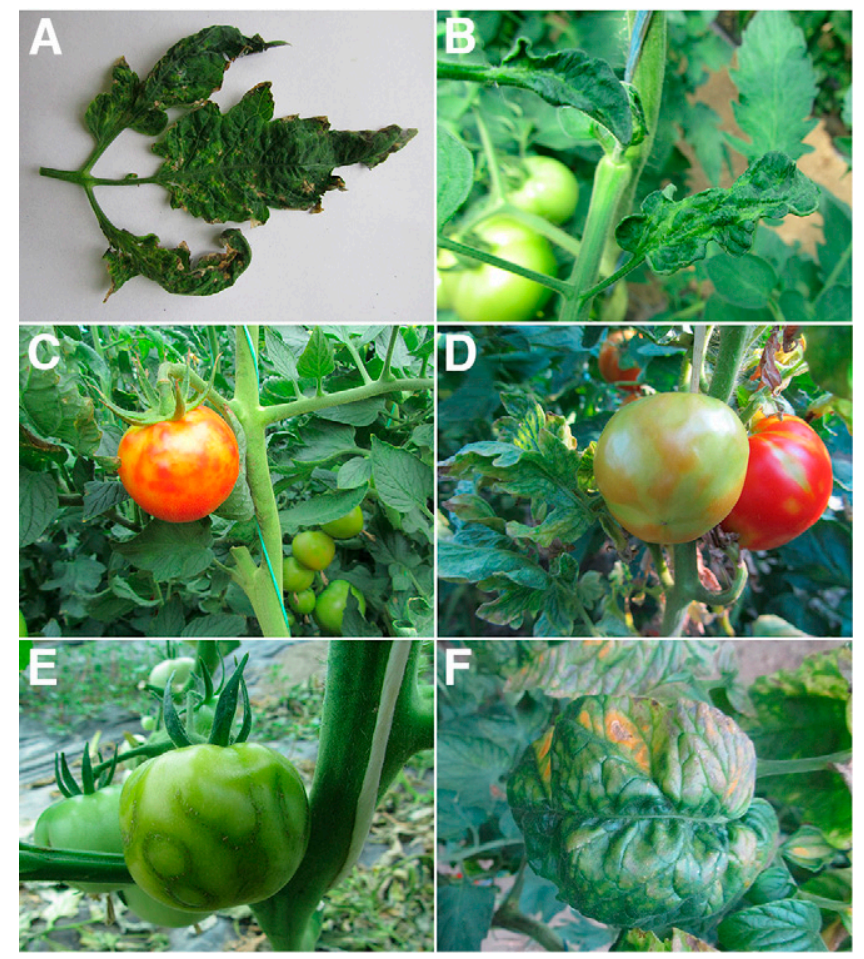

Fig. 1. Possible disease symptoms on the leaves and fruits of sampled tomato plants. A, Edge necrosis, deformation, and mosaic (13-12). B, Mosaic, distortion, and blistering (232-11). C, Marbling (323-12). D, Mosaic and uneven ripening (232-12). E, Necrotic line patterns and deformations (230-13). F, Chlorosis, necrotic spots, and blistering (238-12).
RT-PCR reactions were performed using the One-Step RT-PCR Kit (Qiagen GmbH, Germany) and virus-specific primers and cycling conditions (Supplementary Table S6). The RT-PCR mixture included 400 $\mu \mathrm{M}$ each of the four dNTPs, $0.6 \mu \mathrm{M}$ viral sense and complementary sense primers, $5 \mu \mathrm{l}$ of $5 \times$ Qiagen OneStep RT-PCR Buffer, $1 \mu \mathrm{l}$ of $5 \times$ Q-Solution, $1 \mu \mathrm{l}$ of RT-PCR enzyme mix (Omniscript Reverse transcription, Sensiscript Reverse transcription, and HotStarTaq DNA Polymerase), and $1 \mu \mathrm{l}$ of extracted RNA. The volume of the mixture was adjusted to $25 \mu \mathrm{l}$ by using RNase-Free water. RT-PCR was carried out in the thermal cycler GeneAmp PCR System 9700 (Applied Biosystems). Amplification products, together with the appropriate negative and positive controls (when those were available), were run in $1 \%$ agarose gel stained with ethidium bromide. The sample was considered positive if a band of the expected size was visualized.

Amplification products of the predicted size of two selected ToTV and all three PhCMoV isolates obtained by RT-PCR were sequenced directly after purification with the QIAquick PCR Purification Kit (Qiagen). Sequencing was performed on an automated capillary DNA sequencing system (GATC Biotech AG) using both primers. The consensus nucleotide sequences were compiled and determined by using FinchTV Version 1.4.0. To confirm PhCMoV detection, Sanger sequences were aligned against the respective $\mathrm{PhCMoV}$ genomes obtained by HTS using MEGA X (Kumar et al. 2018). Partial sequences of two ToTV isolates covering part of the Vp23 coat protein gene have been deposited in the NCBI GenBank. Previously developed one-step RT-qPCR assays were performed for TSWV and ToTV (Supplementary Table S6). The RT-qPCRs were prepared in a final volume of $10 \mu \mathrm{l}$ (containing $2 \mu \mathrm{l}$ of sample RNA, $900 \mathrm{nM}$ TSWV/500 nM ToTV primers, and $200 \mathrm{nM}$ TSWV/250 nM ToTV probe) using the AgPathID One-Step RT-qPCR mix (Ambion). The RNA samples were analyzed either undiluted or 10- or 100-fold diluted for ToTV and 10- or 100-fold diluted for TSWV. RT-qPCR was carried out in 384-well plates (Applied Biosystems), and the reactions were run in triplicates on an ABI PRISM 7900HT sequence detection system (Applied Biosystems). The cycling conditions are provided in Supplementary Table S6. A sample was considered positive for ToTV if it produced an exponential amplification curve that was distinguishable from the negative controls; in such cases, the quantification cycles $(\mathrm{Cq})$ were determined. For TSWV, samples were considered positive if their average RT-qPCR Cq values were lower than the determined Cq cutoff value of 35 . The SDS 2.4 software (Applied Biosystems) was used for fluorescence acquisition and determination of $\mathrm{Cq}$ values. For this, the baseline was set automatically, and the fluorescence threshold was set manually to 0.3 (for TSWV) or 0.25 (for ToTV), i.e., to a level that was above the baseline and sufficiently low to be within the exponential increase region of the amplification curve. If no exponential amplification curve was produced, a sample was considered negative.

To ascertain that $\mathrm{PhCMoV}$ isolates detected in our samples are not serologically cross-reacting with the closely related eggplant mottled dwarf virus (EMDV), samples in which the presence of Physostegia chlorotic mottle virus (PhCMoV) was detected were tested using a commercial ELISA diagnostic kit (DSMZ, Braunschweig, Germany) against EMDV, according to manufacturer's instructions. Both commercial positive (DSMZ, Braunschweig, Germany) and negative (extracts from healthy tomato leaf tissue and extraction buffer) controls were included in the test. Samples were considered positive if the absorbance value was equal to or higher than two times the absorbance value of the negative control.

Phylogenetic analyses. Phylogenetic analyses were conducted for STV and PhCMoV, for which complete genome sequences were derived in this study from single samples and for which there was enough sequence data of other isolates in the NCBI GenBank for meaningful analysis. Alignments of complete genome sequences of STV (two sequences generated in this study and all sequences available in the NCBI GenBank nucleotide database; see Supplementary Table S7) and complete amino acid sequences of the polymerase (L) gene of selected plant rhabdoviruses (three sequences generated in this study and selected sequences from the NCBI GenBank nucleotide database; see Supplementary Table S8) were conducted by CLUSTAL W in MEGA X (Kumar et al. 2018). For the alignment of rhabdoviruses, ambiguously aligned amino acid residues were pruned by using 
Gblocks (Castresana 2000) with 650 positions remaining in the final dataset. For both analyses, the most appropriate sequence evolution model was identified according to the Akaike Information Criterion and Bayesian Information Criterion ranking using ModelTest implemented in MEGA X. Phylogenetic analyses were conducted using the maximum likelihood algorithm implemented in MEGA X. The initial tree(s) for the heuristic search were obtained automatically by applying Neighbor-Join and BioNJ algorithms to a matrix of pairwise distances estimated using a Jones-Taylor-Thornton model and then selecting the topology with a superior log likelihood value. A discrete gamma distribution was used to model the evolutionary rate differences among sites (five categories $[+G$, parameter $=2.0698]$ ). The tree with the highest log likelihood was shown. The statistical support of the branches was evaluated using the bootstrap method based on 1,000 replicates. Intragroup and intergroup diversity values were calculated as the average genetic distances using the p-distance model in MEGA X.

\section{Results}

HTS data. In this study, we obtained HTS results for selected samples that we pooled or sequenced separately, finally constructing and sequencing 11 libraries (Table 1). The libraries generated 13,345,833 to $24,445,608$ raw reads each (Supplementary Table S2). After adapter trimming and filtering sRNAs with lengths of 21 to $24 \mathrm{nt}, 1,871,213$ to $12,319,941$ reads were obtained. For all the samples, the amount of filtered sRNA data was above the potentially limiting data size for plant virus detection, reported by empirical analysis of rarefied sRNA datasets (Pecman et al. 2017). The most abundant class of sRNAs was $23 \mathrm{nt}$ in length in seven libraries and $22 \mathrm{nt}$ in length in four libraries. Similar length distributions of sRNA were observed in all the libraries. These sRNA reads have been deposited in the NCBI Sequence Read Archive and allocated under accession nos. SRR8237432 to SRR8237442 (Bioproject No. PRJNA506547).

Virus identification. We detected and confirmed the presence of one or two viruses in each of the six libraries, of which three were constructed from individual samples and three from the pool of samples (Table 1). In total, we detected five different viral species. In four libraries, we detected single infections of STV (Amalgavirus; p_3), ToTV (Torradovirus; p_4), or PhCMoV (Alphaucleorhabdovirus; 232-12 and 238-12). In p_9, we detected a double infection of TSWV (Orthotospovirus) and SpLV (Ilarvirus), and in 323-12, we detected a double infection of PhCMoV and STV.

The genome sequences of the identified viruses from all the libraries have high to moderate ( 93.6 to $100 \%$ ) nt sequence identity with the respective (most similar) isolate genomes from the GenBank database (Table 2). The use of the reliable, generic detection method of HTS thus resulted in the novel detection of four viruses in Serbia (ToTV, $\mathrm{STV}, \mathrm{PhCMoV}$, and SpLV). We did not detect the presence of any virus in 5 of 11 libraries (Table 1).

Complete or near complete genome sequences were covered by sRNA reads for two STV isolates, one SpLV isolate, one ToTV isolate, and three $\mathrm{PhCMoV}$ isolates. The number of reads corresponding to the obtained isolates of different viruses and the average coverage in the final mappings are provided in Supplementary Table S9. Complete consensus genome sequences were reconstructed for STV, SpLV, and $\mathrm{PhCMoV}$ isolates and were deposited in the NCBI GenBank (Table 2). Since ToTV was detected in a pool of 11 samples (Table 1), two samples were selected (12-12 and 15-12) from which parts of the ToTV genome were amplified, Sanger sequenced, and deposited in the NCBI GenBank (Table 2).

Southern tomato virus (STV, genus Amalgavirus). The presence of STV was detected in 2 of 11 libraries, p_3 and 323-12. Using RT-PCR, STV was confirmed in one (isolate 232-11) of two samples pooled in p_3 and in the single sample 323-12 (Table 1). The sequence of the isolate $232-11$ exhibited $99.9 \%$ nt identity with the STV sequence from Mexico (EF442780), while 323-12 exhibited 99.9\% identity with the STV sequence from the United Kingdom (KY810783).

A maximum likelihood phylogenetic analysis of the STV isolates (Fig. 2), based on the Hasegawa-Kishino-Yano model, revealed two major groups of STV isolates (groups 1 and 2). The STV isolates from Serbia (232-11 and 323-12) clustered into group 1. Within group 1, isolate 232-11 clustered into a subgroup with an isolate from the United Kingdom.

Spinach latent virus ( $S p L V$, genus Ilarvirus). We detected SpLV in one pool of samples (p_9). Using RT-PCR, SpLV was confirmed in one (isolate 230-13) of six individual samples in this pool (Table 1). This Serbian SpLV 230-13 isolate exhibited the highest nucleotide identities with the spinach isolate from the United States (KY695012-14) in all three segments: RNA1, RNA2, and RNA3 (99.9, 99.8, and $100 \%$, respectively).

Tomato spotted wilt orthotospovirus (TSWV, genus Orthotospovirus). Besides SpLV, TSWV also was detected in the p_9 library. Using RT-qPCR, TSWV was confirmed in five of six individual samples in this pool; both SpLV and TSWV were found to be present in sample 230-13 (Table 1). The Cq values of TSWV-positive samples ranged from 22.7 to 32.3 (Table 1). sRNA reads mapped to all three genomic RNAs of TSWV (RNA S, RNA M, and RNA L); however, we were unable to extract whole genome sequences for any of the RNAs because of insufficient coverage (Supplementary Table S9).

Tomato torrado virus (ToTV, genus Torradovirus). We detected the presence of ToTV in the p_4 library. Using RT-PCR and RT-qPCR, ToTV was confirmed in all of the samples $(n=11)$ comprising the p_4 pool (Table 1). RT-qPCR ToTV-positive samples had Cq values from 20.3 to 36 (Table 1). Sanger sequences of a part of the coat protein gene (Vp23) on RNA2 from both selected individual samples (12-12 and 15-12) exhibited the highest nucleotide identities $(99.82 \%$ with $100 \%$ amino acid identity) with two ToTV isolates from South Africa and Spain (MH587230 and GQ397402, respectively). These two Serbian isolates were identical in this part of their genomes.

Physostegia chlorotic mottle virus (PhCMoV, genus Alphanucleorhabdovirus). We detected the presence of $\mathrm{PhCMoV}$ in 3 (23212, 238-12, and 323-12) of 11 libraries; all three libraries represented individual samples. The obtained sequences of 232-12, 238-12, and $323-12$ were $13,318,13,315$, and $13,316 \mathrm{nt}$ in length, respectively. The isolates 232-12 and 323-12 exhibited the highest nucleotide identities with the Austrian PhCMoV isolate KY636164 (96.5 and 93.6\%, respectively), while isolate $238-12$ exhibited the highest nucleotide

Table 2. Comparison of the whole and partial genome sequences of viruses detected by HTS in tomato samples from Serbia with the most similar reference sequence available in the NCBI GenBank

\begin{tabular}{|c|c|c|c|c|c|c|c|}
\hline $\begin{array}{l}\text { Sequenced } \\
\text { pool }\end{array}$ & $\begin{array}{c}\text { Virus } \\
\text { detected }^{\mathrm{a}}\end{array}$ & $\begin{array}{l}\text { NCBI GenBank } \\
\text { accession no. }\end{array}$ & Isolate & $\begin{array}{c}\text { Genome } \\
\text { part }\end{array}$ & $\begin{array}{c}\text { Reference sequence } \\
\text { accession no. } \\
\text { (NCBI GenBank)/Origin }\end{array}$ & $\begin{array}{l}\text { Host plant of } \\
\text { reference sequence }\end{array}$ & $\begin{array}{c}\% \text { of identity } \\
\text { with the reference }\end{array}$ \\
\hline p_3 & STV & MT269808 & $232-11$ & Whole & KY810783/UK & Tomato & 99.9 \\
\hline 232_12 & $\mathrm{PhCMoV}$ & MT269810 & $232-12$ & Whole & KX636164/Austria & Physostegia & 96.5 \\
\hline 238_12 & $\mathrm{PhCMoV}$ & MT269811 & $238-12$ & Whole & KY859866/Germany & Tomato & 93.6 \\
\hline \multirow[t]{3}{*}{ p_9 } & SpLV & MT269813 & $230-13$ & RNA1 & KY695012/U.S.A. & Spinach & 99.9 \\
\hline & & MT269814 & & RNA2 & KY695013/U.S.A. & Spinach & 99.8 \\
\hline & & MT269815 & & RNA3 & KY695014/U.S.A. & Spinach & 100 \\
\hline \multirow[t]{2}{*}{$323 \_12$} & STV & MT269809 & $323-12$ & Whole & EF442780/Mexico & Tomato & 99.9 \\
\hline & $\mathrm{PhCMoV}$ & MT269812 & & Whole & KX636164/Austria & Physostegia & 93.6 \\
\hline \multirow[t]{2}{*}{ p_4 } & ToTV & MT269806 & $12-12$ & Vp23 & MH587230, GQ397402/ & Unknown host, & \\
\hline & & MT269807 & $15-12$ & Vp23 & South Africa, Spain & black nightshade & 99.8 \\
\hline
\end{tabular}

${ }^{\mathrm{a}} \mathrm{STV}$, southern tomato virus; PhCMoV, physostegia chlorotic mottle virus; SpLV, spinach latent virus; ToTV, tomato torrado virus. 
identity with the German PhCMoV isolate KY859866 (93.6\%). All three samples were negative for the presence of EMDV in ELISA test (Table 1).

A maximum likelihood tree (Fig. 3A) based on the Le_Gascuel_2008 $(\mathrm{LG}+\mathrm{G})(\mathrm{Le}$ and Gascuel 2008) model, reconstructed based on the alignment of complete amino acid $\mathrm{L}$ gene sequences of three Serbian $\mathrm{PhCMoV}$ isolates and 27 other plant-infecting representatives of Rhabdoviridae, revealed that $\mathrm{PhCMoV}$ isolates are clustered together with other Alphanucleorhabdovirus species. The PhCMoV cluster was monophyletic and showed close evolutionary relations with the EMDV cluster. The genetic distance between these two clusters was $0.0671 \pm 0.009$, while the average genetic distance was $0.01 \pm 0.003(\mathrm{PhCMoV})$ and $0.003 \pm 0.001$ (EMDV) within each cluster. The Serbian isolates 23812 and 323-12 subclustered with all other sequenced isolates of the species with a relatively low bootstrap support, while the Serbian isolate 232-12 represents a separate species group on the tree (Fig. 3B).

\section{Discussion}

In this study, we detected the presence of TSWV, which is known to be present at many localities in Serbia (Krstić and Bulajić 2007), in addition to other viruses that had never been described in Serbia before: STV, SpLV, ToTV, and PhCMoV. This was enabled by post hoc analysis of selected tomato samples from a large survey (Nikolić 2018; Nikolic et al. 2018) that had tested negative using selective targeted tests. Thus, we were able to detect known and important pathogens of tomato (ToTV, TSWV), potential latent viruses (STV, SpLV), and a discovered, possibly emerging tomato pathogen (PhCMoV). HTS also enabled rapid sequencing of their genomes.

We detected STV in a single infection in tomato with leaf crinkling and mosaic. In a report from Germany, STV was detected in tomato plants showing mottling, yellowing, and/or chlorotic spots in a single infection (Gaafar et al. 2019). Additionally, we found STV in a mixed infection with $\mathrm{PhCMoV}$ in the sample exhibiting fruit mottling. The majority of studies regarding STV have reported mixed infection with other viruses; these studies indicated a possible enhancement in symptom severity but also indicated an inability to distinguish the symptoms caused by only STV (Candresse et al. 2013; Iacono et al. 2015; Padmanabhan et al. 2015b; Sabanadzovic et al. 2009). Although the data on the presence of STV in different countries are available (Candresse et al. 2013; Gaafar et al. 2019; Iacono et al. 2015; Padmanabhan et al. 2015a, b; Verbeek at al. 2015), the foliar or fruit symptoms, the relevant damage and potential losses that STV causes in tomato production, remain to be investigated. The phylogenetic tree we reconstructed from all the available sequences suggested the existence of two STV groups. The larger group included Serbian isolates from this study and isolates from all over the world, which indicates that the intensive international trade and seed transmission of the virus can be responsible for its worldwide distribution (Candresse et al. 2013; Padmanabhan et al. 2015b; Sabanadzovic et al. 2009). The second group only consisted of three isolates from Switzerland and China. Simultaneous reports of STV all over the world are probably caused by both efficient seed transmission and the frequent use of HTS for the detection of tomato-infecting viruses. In the future, special attention should be paid to the presence and distribution of this virus in tomato fields in Serbia because its implications for disease development in tomato are not yet known.

SpLV was detected in only one of six samples from one locality. This is the first evidence for the presence of SpLV in Serbia. Although only a few whole genome sequences of SpLV isolates are available in the GenBank, the Serbian isolate from tomato is $>99 \%$ identical with the spinach SpLV isolate from the United States. SpLV was first described as a symptomless virus in spinach (Bos et al. 1980); however, it was later suggested to also be connected with symptoms on tomato fruits (Lebas et al. 2007). In our study, SpLV was found in a mixed infection with TSWV, thus clear association with observed symptoms is not possible. Because there are only few reports regarding SpLV in tomato (Lebas et al. 2007; Vargas Asencio et al. 2013), the

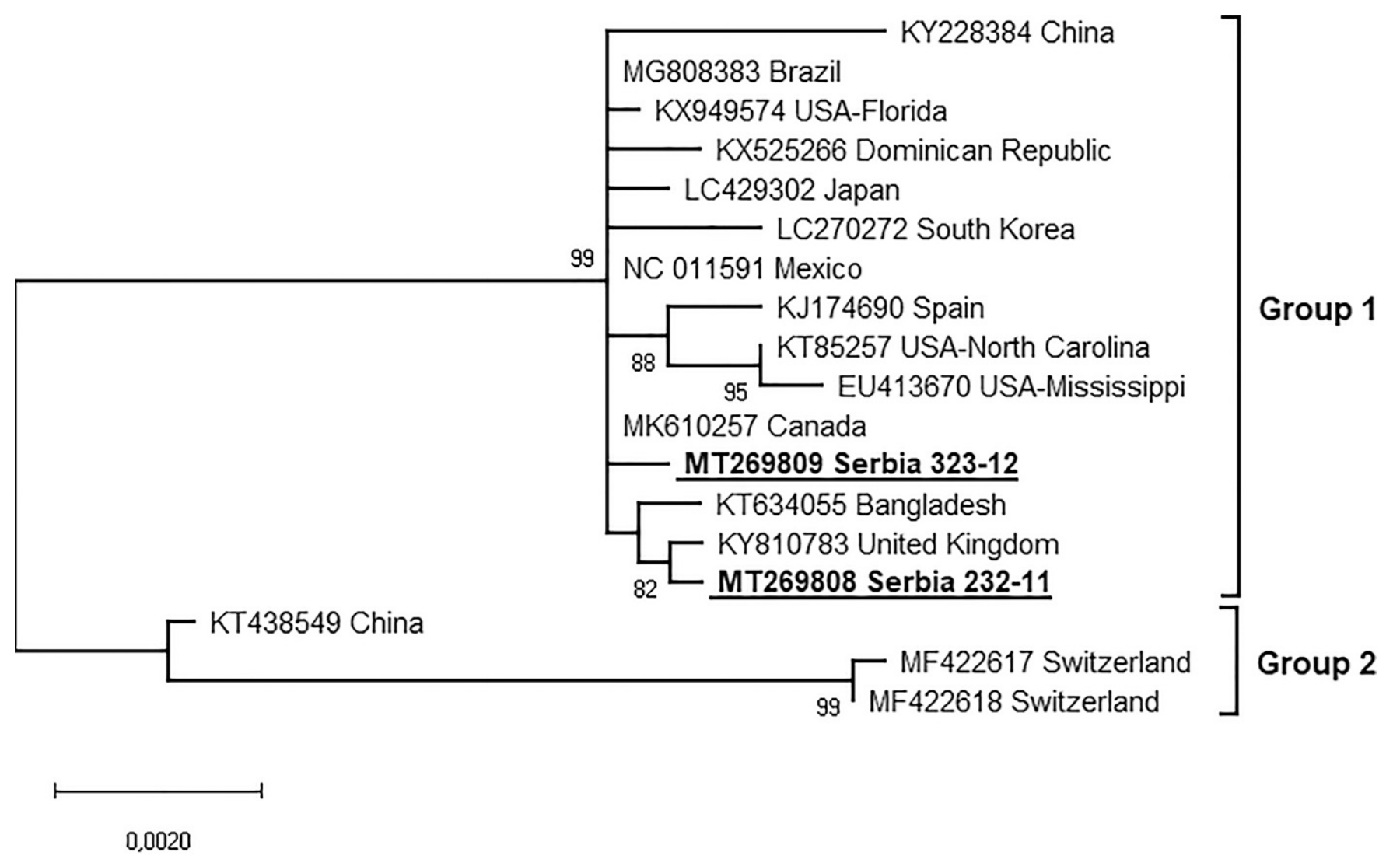

Fig. 2. Maximum likelihood phylogenetic tree based on the complete genome sequences of 18 Southern tomato virus isolates. The phylogram was generated with MEGA $X$ using the Hasegawa-Kishino-Yano model. Bootstrap analysis was performed with 1,000 replicates, and bootstrap values (>50\%) are shown next to the branches. The Serbian southern tomato virus isolates are bolded and underlined. 
virus probably does not represent a significant threat for tomato production at the moment, however, its epidemiology in tomato is still unknown.

TSWV was present in five of six samples from the same pool/locality as SpLV, indicating that this virus probably causes the symptoms observed in the plants of this pool, including leaf mottling and deformations and ring necrosis on fruits. The samples of this pool tested negative for TSWV by ELISA and RT-PCR in a previous study (Nikolić 2018; Nikolić et al. 2018). The inability of ELISA and RT-PCR tests to detect the presence of TSWV could be caused by low virus concentrations in some samples and/or uneven distribution of TSWV in infected plants and leaves (Asano et al. 2017; Đekić et al. 2008), because different leaves were taken from different plant parts for testing with different methods. TSWV is considered one of the most important and widespread tomato viruses in Serbia (Nikolić. 2018; Nikolić et al. 2018), and our results emphasize the need to change the TSWV screening test currently used in Serbia.

HTS of the pooled sample from the Debrc locality (p_4) resulted in the identification of ToTV. ToTV was the only virus detected in a pooled sample of plants displaying distinct symptoms, such as mottling, yellow mosaic, bronzing, necrosis, crinkling, and shoestring, symptoms already associated with ToTV (Alfaro-Fernández et al. 2007; Verbeek et al. 2007, 2008). Outbreaks of ToTV and other torradoviruses are common in many regions (Turina et al. 2007; Verbeek

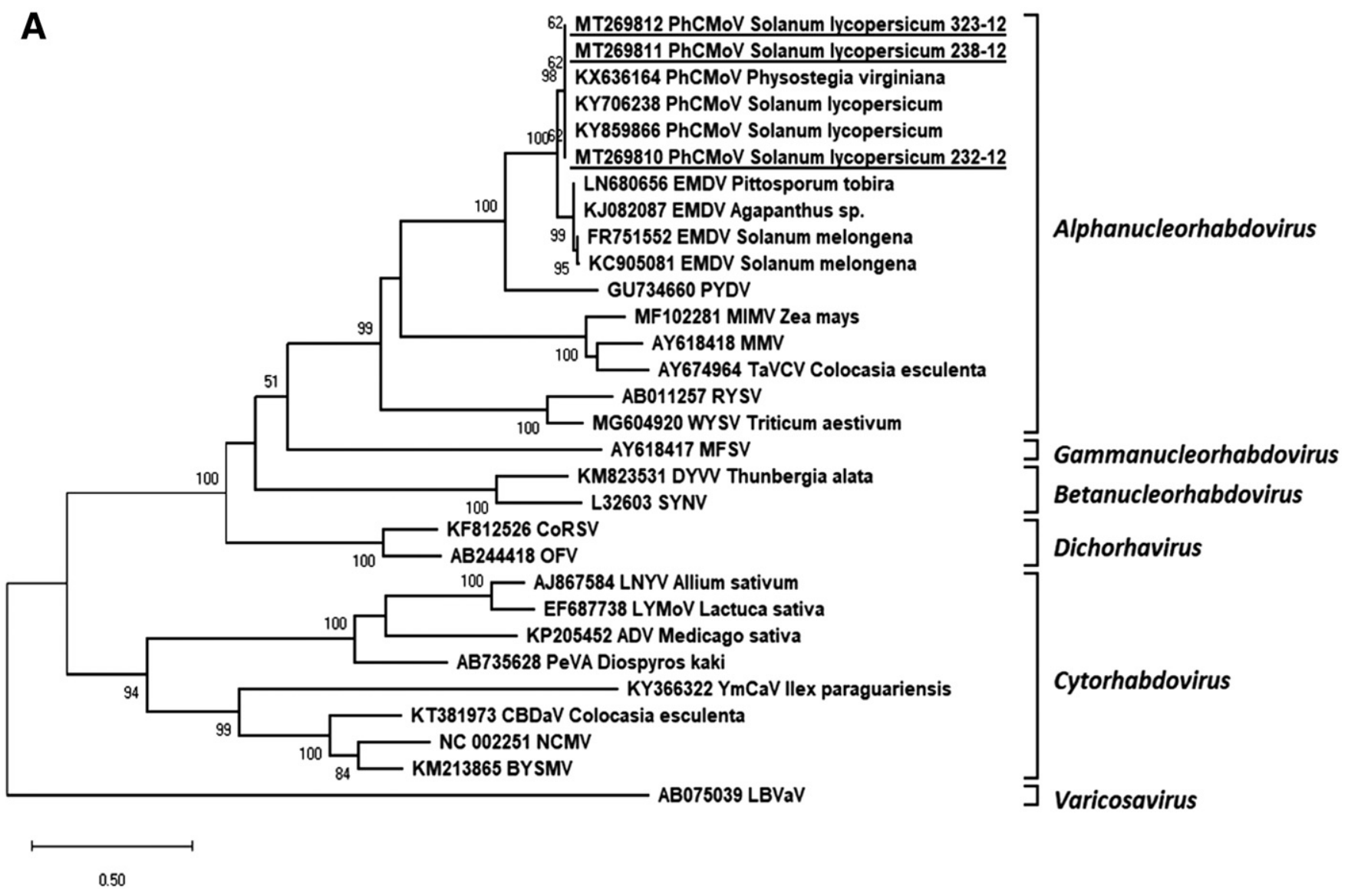

B
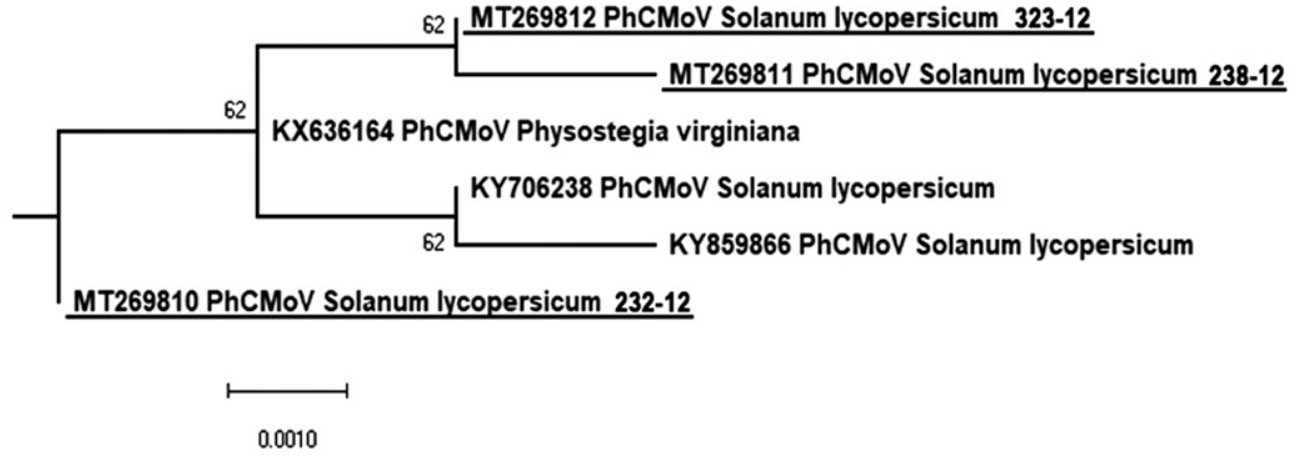

Fig. 3. A, A maximum likelihood phylogenetic tree based on the full-length $L$ gene sequences of 30 species representatives of Alphanucleorhabdovirus, Betanucleorhabdovirus, Gammanucleorhabdovirus, Cytorhabdovirus, Dichorhavirus, and Varicosavirus. B, A subtree of Physostegia chlorotic mottle virus (PhCMoV) isolates. The phylograms were generated with MEGA X using the Le_Gascuel_2008 model with discrete gamma distribution. Bootstrap analysis was performed with 1,000 replicates, and bootstrap values $(>50 \%)$ are shown next to the relevant branches. The Serbian PhCMoV isolates are bolded and underlined. 
et al. 2007, 2008). The outbreak of virus-like symptoms in a greenhouse at the Debrc locality in 2012 resulted in an almost total yield loss. The intensive trading of seeds and plant material and abundant presence of vector species (Trialeurodes vaporariorum) probably led to the outbreak of ToTV in tomato in Serbia. After the first description of ToTV in Spain in 2001, the disease was restricted to small geographical areas, but later on outbreaks have been reported in tomato crops in Hungary, southern France, Poland, Panama, and Australia (AlfaroFernández et al. 2008; EPPO 2009; Herrera-Vásquez et al. 2009; Pospieszny et al. 2007; Verdin et al. 2009; Goméz et al. 2012). Successful eradication of ToTV, in which all infected plants were destroyed, have been reported in Poland, Hungary (Goméz et al. 2012), Belgium, France, and the Netherlands (EPPO 2020) and, in the other parts of Europe, ToTV epidemics were described as transient (Goméz et al. 2012), and the virus was deleted from the EPPO Alert list in 2013 (EPPO 2020). Similarly, in a Serbian greenhouse in which ToTV was found, the removal and destruction of infected tomato material was carried out for the eradication of the, at that time, still unknown causal agent. Since 2012, no similar outbreak with unresolved epidemiology in tomato has been noted during the extensive surveys that have been regularly performed in Serbia (Nikolić 2018; Nikolić et al. 2018). We therefore consider the virus eradication to have been successful. Our novel discovery of ToTV in Serbia using HTS demonstrates that this method is useful for detecting an economically very important pathogen.

This study detected for the first time the presence of $\mathrm{PhCMoV}$ at three different localities in Serbia. PhCMoV was detected in the samples that exhibited leaf and fruit mottling and uneven fruit ripening, symptoms previously reported in plants infected with $\mathrm{PhCMoV}$ (Gaafar et al. 2018; Menzel et al. 2016). This virus was first described in Austria in Physostegia virginiana by Menzel et al. (2016). Later, the same virus was found to be present in samples of tomato from Germany already from 2003 and later in 2015 to 2016 (Gaafar et al. 2018). The ELISA tests using antibodies for the most closely related viral species, i.e., EMDV, performed in our current study as well as the serological tests performed by Gaafar et al. (2018) and Menzel et al. (2018) showed that the two viruses can be clearly distinguished in serological tests, which is one of the criteria for species demarcation within the genus. Our phylogenetic analysis of the three isolates showed grouping of Serbian $\mathrm{PhCMoV}$ isolates with other known $\mathrm{PhCMoV}$ isolates available in the GenBank. Considering the potential importance of $\mathrm{PhCMoV}$, a further characterization of this virus in Serbia is needed to better understand the epidemiology of the virus and the potential ways it could be introduced and spread in Serbia. Although Steinmöller and Ziebell (2017) in the Express pest risk assessment of PhCMoV indicated a low phytosanitary risk for this virus in the European Union, the results of our current study, along with the severe symptoms on tomato and other reports on this virus, suggest that $\mathrm{PhCMoV}$ could be considered an emerging tomato-infecting virus. In addition, the ability of $\mathrm{PhCMoV}$ to infect the representatives of two botanically distant families, $P$. virginiana (Lamiaceae) and tomato (Solanaceae), suggests a potential host range expansion and, therefore, a risk to other susceptible crops.

The results of this study represent the first comprehensive analysis using HTS of the tomato virome in Serbia, complementing the results obtained in the studies on the presence and distribution of tomato viruses in Serbia (Nikolić 2018; Nikolić et al. 2018). Considering the emerging status of ToTV, the description of PhCMoV and STV, and the poorly understood roles of these viruses in tomato disease and their potential importance for the tomato industry, further investigations are needed.

HTS is becoming an important virus-detection tool for plant control, especially for plant import and certification, where it could prevent pathogen spread by international trade (Villamor et al. 2019). The results of our study highlight the importance of the application of HTS in plant virus diagnostics, especially in cases when targeted methods traditionally used in plant virology do not reveal the cause of the disease. The sRNA sequencing method used in this study was shown to be a suitable approach to identify unexpected viruses in plant samples with unknown etiology, as already demonstrated before (Kreuze et al. 2009, Pecman et al. 2017). Other HTS approaches for the detection of plant viruses, such as sequencing of total RNA (Pecman et al. 2017) or double-stranded RNA (Gaafar and Ziebell 2020), will likely bring similar or even slightly superior results regarding the detection of plant viruses. Our study should encourage the use of HTS for pathogen detection in other important cultivated plants in smaller laboratories with limited resources, as it demonstrates that the method can be used on a limited set of samples with a high gain (in terms of detecting new viruses in certain geographical areas) for plant protection purposes.

\section{Acknowledgments}

We thank Larisa Gregur for excellent technical support.

\section{Literature Cited}

Adams, I. P., Glover, R. H., Monger, W. A., Mumford, R., Jackeviciene, E. Navalinskiene, M., Samuitiene, M., and Boonham, N. 2009. Next-generation sequencing and metagenomic analysis: a universal diagnostic tool in plant virology. Mol. Plant Pathol. 10:537-545.

Al Rwahnih, M., Daubert, S., Golino, D., and Rowhani, A. 2009. Deep sequencing analysis of RNAs from a Grapevine showing Syrah decline symptoms reveals a multiple virus infection that includes a Novel virus. Virology 387: 395-401.

Alfaro-Fernández, A., Córdoba-Sellés, C., Cebrián, M. C., Font, M., Juárez, V. Median, A., Lacasa, A., Sánchez-Navarro, J. A., Pallas, V., and Jordá-Gutiérrez, C. 2007. Advances in the study of Tomato "Torrao" or "Cribado" syndrome. Bol. Sanid. Veg., Plagas 33:99-109.

Alfaro-Fernández, A., Córdoba-Sellés, C., Cebrián, M. C., Herrera-Vásquez, J. A., Sánchez-Navarro, J. A., Juárez, M., Espino, A., Martín, R., and Jordá, C. 2008. First report of tomato torrado virus on weed hosts in Spain. Plant Dis. 92:831.

Asano, S., Hirayama, Y., and Matsushita, Y. 2017. Distribution of Tomato spotted wilt virus in dahlia plants. Lett. Appl. Microbiol. 64:297-303.

Bankevich, A., Nurk, S., Antipov, D., Gurevich, A. A., Dvorkin, M., Kulikov, A. S., Lesin, V. M., Nikolenko, S. I., Pham, S., Prjibelski, A. D., Pyshkin, A. V., Sirotkin, A. V., Vyahhi, N., Tesle, G., Alekseyev, M. A., and Pevzner, P. A. 2012. SPAdes: a new genome assembly algorithm and its applications to single-cell sequencing. J. Comput. Biol. 19:455-477.

Bos, L., Huttinga, H., and Maat, D. Z. 1980. Spinach latent virus, a new ilarvirus seed-borne in Spinacia oleracea. Neth. J. Plant Pathol. 86:79-98.

Candresse, T., Marais, A., and Faure, C. 2013. First report of Southern tomato virus on tomatoes in Southwest France. Plant Dis. 97:1124.

Castresana, J. 2000. Selection of conserved blocks from multiple alignments for their use in phylogenetic analysis. Mol. Biol. Evol. 17:540-552.

Coetzee, B., Freeborough, M. J., Maree, H. J., Celton, J. M., Rees, D. J. G., and Burger, J. T. 2010. Deep sequencing analysis of viruses infecting grapevines: virome of a vineyard. Virology 400:157-163.

Đekić, I., Bulajić, A., Vučurović, A., Ristić, D., and Krstić, B. 2008. Influence of Tomato spotted wilt virus uneven distribution on its serological detection in tomato, pepper and ornamentals. Pestic Phytomed 23:225-234 (in Serbian).

EPPO. 2009. First record of tomato torrado virus in Australia. EPPO Reporting Service No. 2, 2009. https://gd.eppo.int/reporting/article-115

EPPO. 2020. EPPO Global Database (GD). https://gd.eppo.int/taxon/TOTV00/ distribution

FAO. 2016. The FAO Statistical Database (FAOSTAT): Food and Agriculture Organization of the United Nations. http://www.fao.org/faostat/en/\#data/ QC\#ancor

Gaafar, Y., Lüddecke, P., Heidler, C., Hartrick, J., Sieg-Müller, A., Hübert, C., Wichura, A., and Ziebell, H. 2019. First report of Southern tomato virus in German tomatoes. New Dis. Rep. 40:1.

Gaafar, Y. Z. A., Abdelgalil, M. A. M., Knierim, D., Richert-Pöggeler, K. R., Menzel, W., Winter, S., and Ziebell, H. 2018. First report of physostegia chlorotic mottle virus on Tomato (Solanum lycopersicum) in Germany. Plant Dis. 102:255

Gaafar, Y. Z. A., and Ziebell, H. 2020. Comparative study on three viral enrichment approaches based on RNA extraction for plant virus/viroid detection using high-throughput sequencing. PLoS One 15:e0237951.

Gómez, P., Sempere, R., and Aranda, M. A. 2012. Pepino mosaic virus and Tomato torrado virus: two emerging viruses affecting tomato crops in the Mediterranean basin. Adv. Virus Res. 84:505-532.

Hanssen, I. M., and Lapidot, M., 2012. Major tomato viruses in the Mediterranean basin. Adv. Virus Res. 84:31-66.

Hanssen, I. M., Lapidot, M., and Thomma, B. P. H. J. 2010. Emerging viral diseases of tomato crops. Mol. Plant-Microbe Interact. 23:539-548.

Herrera-Vásquez, J. A., Alfaro-Fernández, A., Córdoba-Selles, M. C., Cebrian, M. C., Font, M. I., and Jorda, C. 2009. First report of tomato torrado virus infecting tomato in single and mixed infections with Cucumber mosaic virus in Panama. Plant Dis. 93:198.

Hily, J. M., Candresse, T., Garcia, S., Vigne, E., Tannière, M., Komar, V., Barnabé, G., Alliaume, A., Gilg, S., Hommay, G., Beuve, M., Marais, A., 
and Lemaire, O. 2018. High-Throughput Sequencing and the viromic study of grapevine leaves: from the detection of grapevine-infecting viruses to the description of a new environmental Tymovirales member. Front. Microbiol. 9:1782.

Ho, T., and Tzanetakis, I. E. 2014. Development of a virus detection and discovery pipeline using next generation sequencing. Virology 471-473:54-60.

Iacono, G., Hernandez-Llopis, D., Alfaro-Fernandez, A., Davino, M., Font, M. I., Panno, S., Galipenso, L., Rubio, L., and Davino, S. 2015. First report of Southern tomato virus in tomato crops in Italy. New Dis. Rep. 32:27.

Itaya, A., Folimonov, A., Matsuda, Y., Nelson, R. S., and Ding, B. 2001. Potato spindle tuber viroid as inducer of RNA silencing in infected tomato. Mol. Plant-Microbe Interact. 14:1332-1334.

Kreuze, J. F., Perez, A., Untiveros, M., Quispe, D., Fuentes, S., Barker, I., and Simon, R. 2009. Complete viral genome sequence and discovery of novel viruses by deep sequencing of small RNAs: a generic method for diagnosis, discovery and sequencing of viruses. Virology 388:E1-E7.

Krstić, B., and Bulajić, A. 2007. Quarantine Viruses of Vegetebles and Ornamentals in Undercover Crops. University of Belgrade-Faculty of Agriculture, Belgrade, Serbia (in Serbian)

Kumar, S., Stecher, G., Li, M., Knyaz, C., and Tamura, K. 2018. MEGA X: molecular evolutionary genetics analysis across computing platforms. Mol. Biol. Evol. 35:1547-1549.

Kutnjak, D., Silvestre, R., Cuellar, W., Perez, W., Müller, G., Ravnikar, M., and Kreuze, J. 2014. Complete genome sequences of new divergent potato virus X isolates and discrimination between strains in a mixed infection using small RNAs sequencing approach. Virus Res. 191:45-50.

Le, S. Q., and Gascuel, O. 2008. An improved general amino acid replacement matrix. Mol. Biol. Evol. 25:1307-1320.

Lebas, B. S. M., Ochoa-Corona, F. M., Tang, Z. J., Thangavel, R., Elliott, D. R., and Alexander, B. J. R. 2007. First report of Spinach latent virus in tomato in New Zealand. Plant Dis. 91:228.

Lievens, B., and Thomma, B. P. H. J. 2005. Recent developments in pathogen detection arrays: implications for fungal plant pathogens and use in practice. Phytopathology 95:1374-1380.

Massart, S., Olmos, A., Jijakli, H., and Candresse, T. 2014. Current impact and future directions of high throughput sequencing in plant virus diagnostics. Virus Res. 188:90-96.

Menzel, W., Knierim, D., Richert-Pöggeler, K. R., and Winter, S. 2016. Characterization of a nucleorhabdovirus from Physostegia. Julius-Kühn-Arch. 454: 283 (in German).

Menzel, W., Richert-Pöggeler, K. R., Winter, S., and Knierim, D. 2018. Characterization of a nucleorhabdovirus from Physostegia. Acta Hortic. 1193:29-38.

Mijatović, M., Zdravković, J., Marković, Z., and Obradović, A. 2000. Disease intensity of some tomato viruses in Serbia. Acta Physiol. Plant. 22:332-335.

Moyer, J. W., German, T., Sherwood, J. L., and Ullman, D. 1999. An update on Tomato spotted wilt virus and related tospoviruses. APSnet Features. Online publication. doi: 10.1094/APSnetFeatures-1999-0499

Nikolić, D., Vučurović, A., Stanković, I., Radović, N., Zečević, K., Bulajić, A., and Krstić, B. 2018. Viruses affecting tomato crops in Serbia. Eur. J. Plant Pathol. 152:225-235.

Nikolić, D. M. 2018. Diversity and characterization of tomato viruses in Serbia. Doctoral dissertation, University of Belgrade-Faculty of Agriculture, Belgrade, Serbia (in Serbian)

Padmanabhan, C., Zheng, Y., Li, R., Fei, Z., and Ling, K. 2015a. Complete genome sequence of Southern tomato virus naturally infecting tomatoes in Bangladesh. Genome Announc. 3:e01522-15.

Padmanabhan, C., Zheng, Y., Li, R., Sun, S., Zhang, D., Liu, Y., Fei, Z., and Ling, K. 2015b. Complete genome sequence of Southern tomato virus identified in China using next-generation sequencing. Genome Announc. 3:e01226-15.

Pecman, A., Kutnjak, D., Gutiérrez-Aguirre, I., Adams, I., Fox, A., Boonham, N., and Ravnikar, M. 2017. Next generation sequencing for detection and discovery of plant viruses and viroids: comparison of two approaches. Front Microbiol. 8:1998.

Pecman, A., Kutnjak, D., Mehle, N., Tušek-Žnidarič, M., Gutierrez Agirre, J., Pirnat, P., Adams, I., Boonham, N., and Ravnikar, M. 2018. High-throughput sequencing facilitates characterisation of a "forgotten" plant virus: the case of a henbane mosaic virus infecting tomato. Front. Microbiol. 9:2739.

PKS. 2019. Chamber of commerce and industry of Serbia. https://pks.rs/

Pospieszny, H., Borodynko, N., Obrepalska-Steplowska, A., and Hasiow, B 2007. The first report of tomato torrado virus in Poland. Plant Dis. 91:1364.

Sabanadzovic, S., Valverde, R. A., Brown, J. K., Martin, R. R., and Tzanetakis, I. E. 2009. Southern tomato virus: the link between the families Totiviridae and Partitiviridae. Virus Res. 140:130-137.

Steinmöller, S., and Ziebell, H. 2017. Express - PRA for Physostegia chlorotic mottle virus - Occurrence. EPPO, Paris, France. https://pra.eppo.int/pra/ b732b1d8-c3e2-4287-816c-4f328b54f027

Turina, M., Ricker, M. D., Lenzi, R., Masenga, V., and Ciuffo, M. 2007. A severe disease of tomato in the Culiacan area (Sinaloa, Mexico) is caused by a new picorna-like vira species. Plant Dis. 91:932-941.

Vargas-Asencio, J., McLane, H., Bush, E., and Perry, K. L. 2013. Spinach latent virus Infecting Tomato in Virginia, United States. Plant Dis. 97:1663.

Verbeek, M., Dullemans, A. M., Espino, A., Botella, M., Alfaro-Fernández, A., and Font, M. I. 2015. First report of Southern tomato virus in tomato in the Canary Islands, Spain. J. Plant Pathol. 97:392.

Verbeek, M., Dullemans, A. M., van den Heuvel, J. F. J. M., Maris, P. C., and van der Vlugt, R. A. A. 2007. Identification and characterisation of tomato torrado virus, a new plant picorna-like virus from tomato. Arch. Virol. 152:881-890.

Verbeek, M., Dullemans, A. M., van den Heuvel, J. F. J. M., Maris, P. C., and van der Vlugt, R. A. A. 2008. Tomato marchitez virus, a new plant picornalike virus from tomato related to tomato torrado virus. Arch. Virol. 153: 127-134.

Verdin, E., Gognalons, P., Wipf-Scheibel, C., Bornard, I., Ridray, G., Schoen, L. and Lecoq, H. 2009. First report of Tomato torrado virus in tomato crops in France. Plant Dis. 93:1352.

Villamor, D. E. V., Ho, T., Al Rwahnih, M., Martin, R. R., and Tzanetakis, I. E. 2019. High throughput sequencing for plant virus detection and discovery. Phytopathology 109:716-725.

Visser, M., Bester, R., Burger, J. T., and Maree, H. J. 2016. Next-generation sequencing for virus detection: covering all the bases. Virol. J. 13:85.

Vučurović, A., Stanković, I., Zečević, K., Petrović, B., Delibašić, G., and Krstić, B. 2019. First report of Tomato infectious chlorosis virus on tomato in Serbia Book of Abstracts of VIII Congress on Plant Protection: Integrated Plant Protection for Sustainable Crop Production and Forestry, November 25-29, 2019, Zlatibor, Serbia, pp. 188

Wang, Q., Jia, P., and Zhao, Z. 2013. Virus Finder: software for efficient and accurate detection of viruses and their integration sites in host genomes through next generation sequencing data. PLoS One 8:e64465.

Wickes, B. L., and Wiederhold, N. P. 2018. Molecular diagnostics in medical mycology. Nat. Commun. 9:5135.

Xu, C., Sun, X., Taylor, A., Jiao, C., Xu, Y., Cai, X., Wang, X., Ge, C., Pan, G., Wang, Q., Fei, Z., and Wang, Q. 2017. Diversity, distribution, and evolution of tomato viruses in China uncovered by small RNA sequencing. J. Virol. 91: e00173-17.

Zhao, G., Krishnamurthy, S., Cai, Z., Popov, V. L., Travassos da Rosa, A. P., Guzman, H., Cao, S., Virgin, H. W., Tesh, R. B., and Wang, D. 2013. Identification of novel viruses using VirusHunter-anautomated data analysis pipeline. PLoS One 8:e78470.

Zheng, Y., Gao, S., Padmanabhan, C., Li, R., Galvez, M., Gutierrez, D., Fuentes S., Ling, K. S., Kreuze, J., and Fei, Z. 2017. Virus Detect: an automated pipeline for efficient virus discovery using deep sequencing of small RNAs. Virology 500:130-138. 